\title{
DETECTION OF RETICULOENDOTHELIOSIS VIRUS AS CONTAMINANT OF FOWL POX VACCINES
}

\author{
H. S. Abd El Hamid"; Awad, A. M. ${ }^{* *}$; Abou-Rawash A. A. ${ }^{* *}$; \\ Ellakany, H.F. ${ }^{* * *}$ and Ebrahim H. H. ${ }^{* * * *}$ \\ *Dept. of Avian and Aquatic Animal Medicine, Fac. of Vet. Med., \\ Damanhour Branch, Alex Univ.
}
** Dept. of Pathology and Parasitology, Fac. of Vet. Med., Damanhour Branch, Alex Univ.
*** Dept. of Avian and Aquatic Animal Medicine, Fac. of Vet. Med., Edfina, Alex Univ.
**** Center Lab. for Evaluation of Veterinary Biologics, Abbassia , Cairo.

\begin{abstract}
This study was performed to detect reticuloendotheliosis virus (REV) as a contaminant in fowl pox vaccines. A total of 30 fowl pox vaccine samples for the presences of REV using the in vitro a total and in vivo methods. In the in vitro test, the fowl pox vaccine samples were inoculated into chicken embryo fibroblast (CEF) cultures prepared from SPF embryonated chichen egg and examined by PCR test for detection of REV. In the in vivo test, each fowl pox vaccine sample was inoculated in five days old SPF chicks and kept under observation up to 12 weeks post inoculation (PI); serum samples were collected on 15th, 30th and 45th day PI for the detection of antibodies against REV by commercial ELIZA kit, and tissue specimens were collected at 8th and 12th weeks PI for histopathological examination. The results revealed that: only one imported vaccine sample gave positive results by PCR test a product of 291- bp was obtained by the vaccine sample.
\end{abstract}


H. S. Abd El Hamid et al.,

Serum samples collected from positive vaccine batch were tested for REV antibodies by ELIZA test and the sera were positive. Histopathological examination of liver, spleen and bursa of fabricius revealed the presence of tumor cells in the organs examined and these changes confirmed the results obtained by PCR and ELIZA test and indicated that the sample is contaminated with REV. The data clearly indicated that screening of all commercial poultry vaccine to be virus free is an important factor in assuring the biosafety of animal vaccines.

\section{INTRODUCTION}

Pathogens of poultry constitute one of the major problems facing the poultry industry in Egypt causing severe economic losses. For this reason, the vaccines are a major factor in programs to bring the economically important diseases under control. So, they must be safe for the birds, potent and at the same time, free from any biological contaminants either bacterial, fungal or viral .

Some of these vaccines are locally produced and the others are imported. In Egypt, approximately over $90 \%$ of the vaccines needed by the poultry industry are imported from different producers in Europe and USA.In the last few years, REV was considered as one of the most important vaccine contaminant(Fadly et al., 1996). Reticuloendotheliosis virus is an avian retrovirus and oncovirus that is antigenically and structurally unrelated to viruses of the leucosis/sarcoma group. Also, it is associated with immunosuppression, runting and neoplasia in domestic poultry and other avian species (Witter, 1991). Dren et al. (1988) observed a chronic neoplasia associated with REV in geese. Also, the most common clinical diseases induced by REV are tumors,

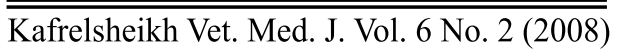


immunosuppression and runting disease (Witter and Fadly, 2003). Nicholas and Thornton (1983), Stated that the REV is considered a potential hazard in the use of chicken embryos and cells for preparation of vaccines. Moreover, REV infection persist on the same production sites over period of several year (Bagust, 1993).

REV has been isolated from Marek's disease vaccines (Yuasa et al., 1976). Jackson et al. (1977) reported a case of high mortalities with nervous symptoms and feathering abnormalities (Nakanuke) in chickens vaccinated with MD vaccine at one day old, these case attributed to REV which was detected as vaccine contaminant in one commercial vaccine batch. Bagust and Dennett (1977) isolated REV from commercial MD vaccine (HVT) by serial passages of REV contaminated vaccine on CEF and detected REV antigen using FA test.

In Middle East and Africa, a REV associated lymphoma not related to contaminated vaccine have been reported (Meroz, 1992 and Okoye et al., 1993). On the other hand, in United States Fadly et al. (1996) reported an outbreak of lymphomas in two broiler breeder flocks following the using of REV contaminated fowl pox vaccine.

Evidence of the widespread occurrence of REV sequence insertions in fowl pox virus (FPV) genome of field isolates and vaccine strains has increased in the recent years (Diallo et al., 1998 and Garcia et al., 2003).

Very recently Singh et al., (2003 and 2005) evidenced that fowl pox virus infection causes lymphoproliferative response in chicken. They also pointed out that an infectious reticuloendotheliosis provirus is present in the majority of the field fowl pox virus genome. Current strains of FPV carrying circulating reticuloendotheliosis virus sequence are becoming more pathogenic to poultry (Tadese et al., 2008). 
Fadly and Garcia (2006) reviewed the most common methods used for testing live virus vaccines of poultry for contamination with REV

The present study aimed to screen our locally produced and imported fowl pox vaccines used in our poultry production in Egypt for the presence of REV through isolation of reticuloendotheliosis virus (REV) from fowl pox vaccines by inoculation of chicken embryo fibroblast (CEF), identification using PCR test, inoculation of fowl pox vaccine in SPF chickens, serological detection of antibody against REV in inoculated SPF chickens using ELISA test and histopathological examination of SPF chickens inoculated with REV isolate.

\section{MATERIAL AND METHODS}

\section{Vaccine Samples:}

Different batches of fowl pox vaccines either imported or locally produced were examined for detection of reticuloendotheliosis virus (REV) as a contaminant. A total of 30 fowl pox vaccine batches ( 4 batches are locally produced and 26 batches are imported) were examined in this study. Each vaccine batch was represented by 6 vials: two were pooled and propagated on CEF culture then examined by PCR and two were pooled and inoculated in SPF chicks, where the other two vials were kept at $+4 \mathrm{C}$ for eventual need.

\section{Specific pathogen free (SPF) fertile eggs and Chickens:}

A total of 250 SPF fertile chicken eggs were obtained from SPF Farm located at Koum Osheim, Fayoum Province. Twenty chicken embryos 9-11days old were used for preparation of CEF culture and the others were kept in the incubator until hatching. A total of 200, five dayold SPF chickens were used for experimental infection. 
Media and solutions for tissue culture:

\section{Tissue culture media:}

Dehydrated Eagl's minimum essential medium (MEM), Sigma, USA, with Eagl's salts and L-glutamine without sodium bicarbonate was used. It was reconstituted in double distilled water, $\mathrm{pH}$ was adjusted to 7.2 and finally sterilized by filtration through 0.95 millipore membrane filter. Inactivated fetal calf serum was added in concentration of $5 \%$ for growth medium and $2 \%$ in maintenance medium. Antibiotics (penicillin 1000IU and streptomycin $500 \mu \mathrm{g}$ )were added at $1 \mathrm{ml}$ stock $/ 100 \mathrm{ml}$ medium.

Testing of vaccines for REV contamination by tissue culture inoculation:

\section{Preparation of the inoculum:}

The preparation of fowl pox vaccine sample for detection of REV contamination using tissue culture was carried out according to Fadly et al., (1996) as following: The fowl pox vaccine sample was reconstituted in $10 \mathrm{ml} \mathrm{MEM}$ then ten fold serial dilutions were carried out until reach the dilution containing 10 bird dose/ml.

\section{Inoculation of the prepared inocula:}

The prepared vaccines were inoculated on drained secondary CEF cultures planted in 6 well tissue culture plates and incubated for 30 minutes at $37{ }^{\circ} \mathrm{C}$ for adsorption, negative cells control represented by one uninoculated well, maintenance medium (with $2 \%$ calf serum) was added to all wells and the plates were incubated at $37 \mathrm{C}$ in $5 \% \mathrm{CO} 2$ incubator for 4 days with daily observation. 


\section{Harvesting the inoculated cultures:}

Four days post inoculation, the plates were subjected to 3 cycles of freezing and thawing then the cell suspension were harvested in small vials and kept at $-70^{\circ} \mathrm{C}$ for detection of $\mathrm{REV}$ by polymerase chain reaction.

\section{Polymerase chain reaction for REV detection:}

\section{Extraction of fowl pox genome:}

1. Commercial kits were used for extraction of fowl pox genome, and the procedures were recommended by the manufacturers (Biobasic Company) as following:

2. $0.5 \mathrm{ml}$ of the sample was harvested in $2.0 \mathrm{ml}$ collection tube then centrifugation at $3000 \mathrm{rpm}$ for 3 minutes at $4 \mathrm{C}$. Discard the supernatant.

3. Add $0.8 \mathrm{ml}$ TBP buffer to the collection tube, vortex gently then centrifuged at $3000 \mathrm{rpm}$ for 3 minutes. Discard supernatant and repeat.

Add $0.5 \mathrm{ml}$ TBM buffer to the collection tube vortex the tube vigorously and then $3 \mu \mathrm{l}$ proteinase-K. Incubate at $55 \mathrm{C}$ for 30 minutes.

4. If insoluble material is visible, centrifuge for 2 minutes at 5,000 rpm. Save the supernatant to $2.0 \mathrm{ml}$ collection tube, then add $360 \mu \mathrm{l}$ absolute ethanol.

5. Apply the mixture to EZ-10 column that is in a $2.0 \mathrm{ml}$ collection tube. Centrifuge at 8,000 rpm for 1 minute, discard the flow through in the collection tube. 
6. Add $500 \mu \mathrm{l}$ of wash solution, and centrifuge at $8,000 \mathrm{rpm}$ for 1 minute and repeat.

7. Discard the flow through centrifuge at $8,000 \mathrm{rpm}$ for 1 minute to remove residual amount of wash solution.

8. Place the column into clean $1.5 \mathrm{ml}$ microfuge tube. Add $30-50$ $\mu 1$ elution buffer into the center part of membrane in the column. Incubate the tube at 37 or $50 \mathrm{C}$ for 3 minutes.

9. Centrifuge at $10,000 \mathrm{rpm}$ for 1 minute to elute DNA from the column.

\section{Polymerase chain reaction test:}

Commercial kits were used in PCR test for detection of REV and the procedures were recommended by the producer (Fermentas Company) as following:

\section{Add in a thin walled PCR tube on ice}

1. $25 \mu 1$ of $2 x$ PCR master mix.

2. 0.1-1.0 $\mu \mathrm{m}$ forward primer

3. 0.1-1.0 $\mu \mathrm{m}$ reverse primer

4. $10 \mathrm{pg}-1 \mathrm{Mg}$ template DNA

5. Water, nuclease-free up to $50 \mu \mathrm{l}$

6. Gently vortex the sample and briefly centrifuge to collect all drops to the bottom of the tube.

7. Overlay the sample with mineral oil or add an appropriate amount of wax.

8. Place the samples in a thermocycler and start the program.

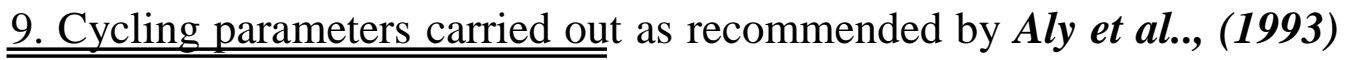
Kafrelsheikh Vet. Med. J. Vol. 6 No. 2 (2008) 
were $94 \mathrm{C}$ for 2 minutes for initial denaturation followed by 39 cycle at $94 \mathrm{C}$ for 1 minute,55C for 2 minutes and $72 \mathrm{C}$ for 1 minutes. A final elongation proceeded at $72 \mathrm{C}$ for 6 minutes.

\section{Experiment (1):}

Testing of vaccines for REV contamination by chickens inoculation:

\section{Preparation of the inoculum:}

The preparation of fowl pox vaccine sample for detection of REV contamination using chickens was carried out according to Fadly and Witter (1997) as following: The fowl pox vaccine sample was reconstituted in MEM at the rate of 100 doses $/ \mathrm{ml}$.

\section{Inoculation of chicken and blood collection:}

The diluted vaccine samples were inoculated in five day old SPF chicks. Each sample was inoculated in five SPF chicks by subcutaneous route with $0.2 \mathrm{ml}$ of the inoculum per chick, and kept in isolator for 45 days post inoculation. Also, there is negative control group of chicks inoculated $\mathrm{S} / \mathrm{C}$ with sterile saline and kept parallel to the inoculated group. After 30 and 45 days post inoculation, blood samples were collected from surviving birds, sera separated and inactivated by heating at $56 \mathrm{C}$ for 30 minutes then kept at $-20 \mathrm{C}$ until tested for REV antibodies by ELISA test.

\section{Detection of REV antibodies by ELISA:}

Commercial ELISA kits (IDEXX Laboratories) were used for detection of REV antibodies in the sera of SPF chickens at 30 and 45 days post inoculation. The procedure of the test was carried out according to the manufacturers.

\section{Experiment (II):}

\section{In vivo assay for detection of REV:}


Fowl pox vaccine no.22 which gave positive results in PCR and ELISA tests was retested in vivo. Prior to chicks inoculation, vaccine sample was reconstituted in MEM at rate of $10 \mathrm{ml} / 1000$ dose. Fifteen - 5 days old SPF chicks were used in this experiment, 10 chicks were inoculated subcutaneously each with $0.2 \mathrm{ml}$ (100 doses of fowl pox vaccine) of the prepared vaccine, and 5 chicks were inoculated with saline and kept as negative control.

All chicks were kept up to 12 weeks post inoculation, serum samples were obtained individually at 15th, 30th and 45th days post inoculation and tested by ELISA for detection of antibodies against REV using commercial ELISA kit.

Further more, by the end of the 8th and 12th weeks post inoculation 5 birds each time were sacrificed and tissue specimens up to $0.5 \mu$ thickness were collected from liver, spleen and bursa of Fabricious for histopathological examination.

\section{Histopathological examination:}

The properly collected tissue specimens from the liver, spleen and bursa of Fabricius were immediately fixed in $10 \%$ neutral buffered formalin solution for at least 24 hours. The fixed specimens were washed in tap water and then processed in ascending grades of ethyl alcohol for dehydration, cleared in xylol and paraffin embedded. Sections of $4-5 \mu$ thick were obtained and then stained with Harris hematoxylin and eosin $(\mathrm{H} \& \mathrm{E})$, mounted in Canada balsam, dried and examined with light microscope (Bancroft and Stevens, 1996).

\section{RESULTS}

Testing of vaccine for REV contamination by tissue culture inoculation: The inoculated SPF cultures were daily observed for 4 days and then the cultures were subjected to 3 cycles of freezing and thawing then the cell suspensions were harvested in small vials and kept at $-70^{\circ} \mathrm{C}$.

PCR test was carried out for detection of REV antigen in vaccine

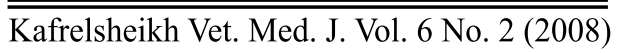


inoculated onto CEF cultures. As shown in figure (1), a product of 291bp was obtained by vaccine sample no. 22 , while other vaccine samples gave negative results.

\section{Testing of vaccines by chicks inoculation:}

The inoculated birds were kept under daily observation for 7 weeks post inoculation and blood samples were collected at both 30 and 45 days post inoculation and sera were separated..

ELISA test using commercial ELISA kits was used for detection of REV antibodies in the sera of SPF chickens previously inoculated with fowl pox vaccine samples.

Data presented in table 1, 2 and 3 showing that one inoculated group of chickens $(3.33 \%$ ) (vaccine no, 22) was positive for REV antibodies at both 30 and 45 days post inoculation, while 29 (96.6\%) out of 30 vaccines inoculated chicks groups were negative for REV antibodies at both 30 and 45 days post inoculation.

\section{Histopathological examination:}

Liver: Hispathological examination of the liver revealed marked atrophy of hepatocytes as a result of pronounced congestion of hepatic sinusoids after 8 and 12 weeks post inoculation (Fig. 2). Foci of mononuclear histiocytic elements (reticuloendothelial elements) infiltration were detected after 12 weeks post inoculation (Fig. 3)

Spleen: Histopathologic examination of the spleen 8 week after inoculation revealed ill-defined multiple focal proliferation of mononuclear histiocytic elements (reticuloendothelial cells) with hyperchromatic nuclei and moderate to abundant slightly basophilic cytoplasms. The cells have a close relation to arterioles in distribution(Fig 4). After 12 weeks the spleen disclosed defuse focal investment with mononuclear histiocytic elements (reticuloendothelial 
cells). The cells showed pronounced pleomorphism, ranged from small rounded, ovoid and large mononuclear histiocytic elements (reticuloendothelial cells), with vesicular nuclei. Some elongated and degenerated cells were also observed. The neoplastic cells had large round to oval vesicular nuclei with prominent chromatin clumps adjacent to the inner surface of the nuclear envelope (Fig. 5, 6).

Bursa of Fabricious: 8 weeks post infiction the bursa of Fabricious showed mild ill defined aggregations of mononuclear histiocytic elements (reticuloendothelial cells) difficult to distinguish from normal bursal lymphoid cells. The cells were inter and intrafolicullary distributed (Fig. 7). 12 weeks post inoculation the bursa showed marked atrophy with moderate inter and intra follicular prolifertation of mononuclear histiocytic elements (reticuloendothelial elements) (Fig. 8, 9). The cells have the same morphology as described in spleen and many of them showed degeneration.

Table (1): Results of ELISA test for detection of REV antibodies in sera of SPF chicks 30 days PI with fowl pox vaccine samples from No.1 to No.10.

\begin{tabular}{|c|c|c|c|c|}
\hline Chick group $n=5$ & $\begin{array}{c}\text { Mean of optical } \\
\text { density }\end{array}$ & $* \mathrm{~S} / \mathbf{P}$ ratio & $\begin{array}{c}\text { No. positive/no. } \\
\text { examined }\end{array}$ & Interpretation \\
\hline $\begin{array}{c}1 \\
2 \\
3 \\
4 \\
5 \\
6 \\
7 \\
8 \\
9 \\
10 \\
\text { uninoculated chicks }\end{array}$ & $\begin{array}{c}0.048 \\
0.0485 \\
0.05 \\
0.052 \\
0.055 \\
0.057 \\
0.053 \\
0.051 \\
0.061 \\
0.059 \\
0.074\end{array}$ & $\begin{array}{c}0.012 \\
0.015 \\
0.017 \\
0.101 \\
0.024 \\
0.027 \\
0.022 \\
0.019 \\
0.034 \\
0.03 \\
0.052\end{array}$ & $\begin{array}{l}0 / 5 \\
0 / 5 \\
0 / 5 \\
0 / 5 \\
0 / 5 \\
0 / 5 \\
0 / 5 \\
0 / 5 \\
0 / 5 \\
0 / 5 \\
0 / 5\end{array}$ & $\begin{array}{l}\text { Negative } \\
\text { Negative } \\
\text { Negative } \\
\text { Negative } \\
\text { Negative } \\
\text { Negative } \\
\text { Negative } \\
\text { Negative } \\
\text { Negative } \\
\text { Negative } \\
\text { Negative }\end{array}$ \\
\hline
\end{tabular}

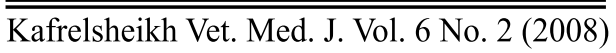


- Negative control mean $(\mathrm{NCM})=0.038$

- Positive control mean $(\mathrm{PCM})=0.7$

- Corrected positive control $(\mathrm{CPC})=0.662$

* S/P ratio more than 0.5 was considered positive for REV antibodies.

Continue Table (1): Results of ELISA test for detection of REV antibodies in sera of SPF chicks 30 days PI with fowl pox vaccine samples from No. 11 to No. 20

\begin{tabular}{||c||c||c||c||c||}
\hline Chick group $\mathrm{n}=5$ & $\begin{array}{c}\text { Mean of optical } \\
\text { density }\end{array}$ & $*$ S/P ratio & $\begin{array}{c}\text { No. positive/no. } \\
\text { examined }\end{array}$ & Interpretation \\
\hline \hline 11 & 0.04 & 0.005 & $0 / 5$ & $0 / 5$ \\
12 & 0.039 & 0.003 & $0 / 5$ & Negative \\
13 & 0.04 & -0.001 & $0 / 5$ & Negative \\
14 & 0.04 & 0.001 & $0 / 5$ & Negative \\
15 & 0.036 & -0.003 & $0 / 5$ & Negative \\
16 & 0.037 & -0.002 & $0 / 5$ & Negative \\
17 & 0.038 & 0.003 & $0 / 5$ & Negative \\
18 & 0.038 & 0.008 & $0 / 5$ & Negative \\
19 & 0.037 & $-0 . .0002$ & $0 / 5$ & Negative \\
20 & 0.038 & 0.0005 & $0 / 5$ & Negative \\
\hline
\end{tabular}

- Negative control mean $(\mathrm{NCM})=0.038$

- Positive control mean $(\mathrm{PCM})=0.485$

- Corrected positive control $(\mathrm{CPC})=0.444$

* S/P ratio more than 0.5 was considered positive for REV antibodies.

Continue Table (1): Results of ELISA test for detection of REV antibodies in sera of SPF chicks 30 days PI with fowl pox vaccine samples from No. 21 to No. 30

\begin{tabular}{|c||c||c||c||c||}
\hline Chick group $\mathrm{n}=5$ & $\begin{array}{c}\text { Mean of optical } \\
\text { density }\end{array}$ & $*$ S/P ratio & $\begin{array}{c}\text { No. positive/no. } \\
\text { examined }\end{array}$ & Interpretation \\
\hline \hline 21 & 0.086 & 0.177 & $0 / 5$ & Negative \\
22 & 0.202 & 0.6 & $5 / 5$ & positive \\
23 & 0.0812 & 0.161 & $0 / 5$ & Negative \\
24 & 0.079 & 0.15 & $0 / 5$ & Negative \\
25 & 0.087 & 0.18 & $0 / 5$ & Negative \\
26 & 0.075 & 0.14 & $0 / 5$ & Negative \\
27 & 0.083 & 0.16 & $0 / 5$ & Negative \\
28 & 0.088 & 0.18 & $0 / 5$ & Negative \\
29 & 0.088 & 0.19 & $0 / 5$ & Negative \\
30 & 0.063 & 0.09 & $0 / 5$ & Negative \\
\hline
\end{tabular}

Kafrelsheikh Vet. Med. J. Vol. 6 No. 2 (2008) 
- Negative control mean $(\mathrm{NCM})=0.039$

- Positive control mean $(\mathrm{PCM})=0.3$

- Corrected positive control $(\mathrm{CPC})=0.26$

* S/P ratio more than 0.5 was considered positive for REV antibodies.

Table (2): Results of ELISA test for detection of REV antibodies in sera of SPF chicks 45 days PI with fowl pox vaccine samples from No. 1 to No.10.

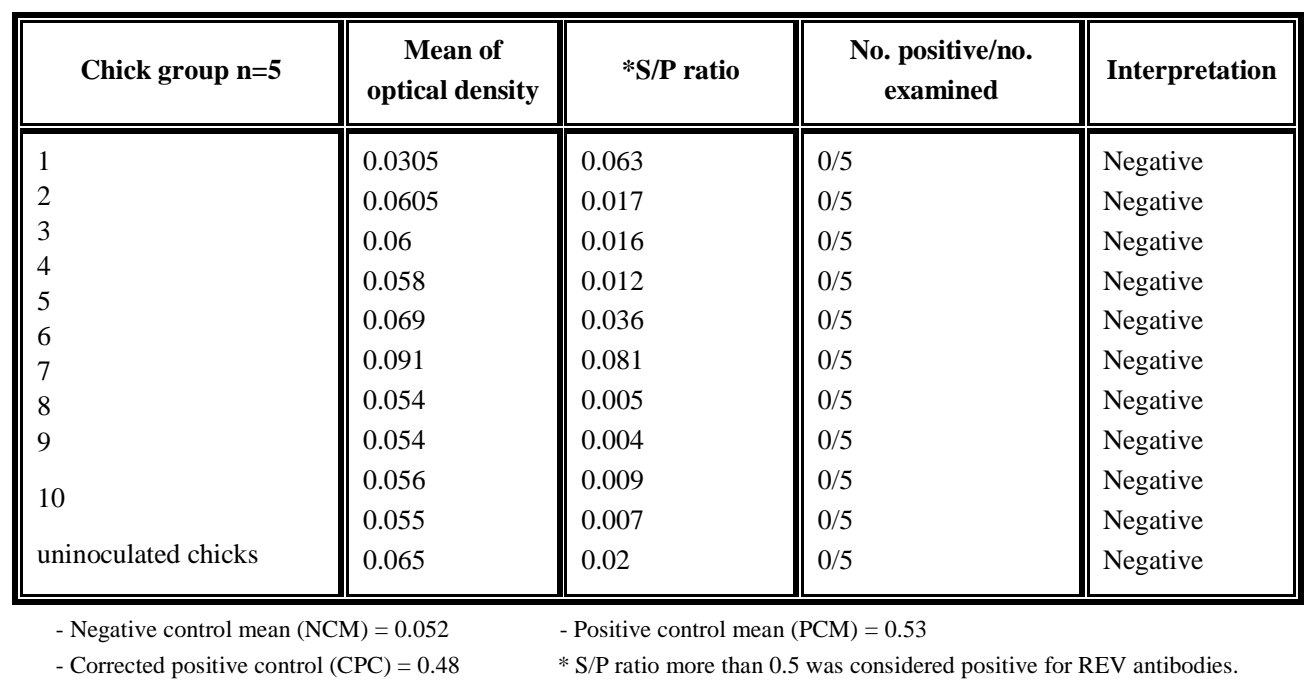

Continue Table (2): Results of ELISA test for detection of REV antibodies in sera of SPF chicks 45 days PI with fowl pox vaccine samples from No. 11 to No. 20.

\begin{tabular}{||l||l||l||l||l||}
\hline \multicolumn{1}{|c||}{ Chick group n=5 } & $\begin{array}{c}\text { Mean of optical } \\
\text { density }\end{array}$ & $*$ S/P ratio & $\begin{array}{c}\text { No. positive/no. } \\
\text { examined }\end{array}$ & Interpretation \\
\hline \hline 11 & 0.038 & -0.0013 & $0 / 5$ & $0 / 5$ \\
12 & 0.036 & -0.006 & $0 / 5$ & Negative \\
13 & 0.037 & -0.003 & $0 / 5$ & Negative \\
14 & 0.039 & 0.0013 & $0 / 5$ & Negative \\
15 & 0.036 & -0.007 & $0 / 5$ & Negative \\
16 & 0.034 & -0.011 & $0 / 5$ & Negative \\
17 & 0.035 & -0.01 & $0 / 5$ & Negative \\
18 & 0.042 & 0.009 & $0 / 5$ & Negative \\
19 & 0.037 & -0.003 & Negative \\
\hline
\end{tabular}

Kafrelsheikh Vet. Med. J. Vol. 6 No. 2 (2008) 


\begin{tabular}{|l||l||l||l||l||}
\hline 20 & 0.036 & -0.006 & $0 / 5$ & Negative \\
uninoculated chicks & 0.035 & -0.01 & Negative \\
\hline
\end{tabular}

- Negative control mean $(\mathrm{NCM})=0.039$

- Corrected positive control $(\mathrm{CPC})=0.38$
- Positive control mean $(\mathrm{PCM})=0.42$

* $\mathrm{S} / \mathrm{P}$ ratio more than 0.5 was considered positive for $\mathrm{REV}$ antibodies.

Continue Table (2): Results of ELISA test for detection of REV antibodies in sera of SPF chicks 45 days PI with fowl pox vaccine samples from No. 21 to No. 30

\begin{tabular}{||c||c||c||c||c||}
\hline Chick group n=5 & $\begin{array}{c}\text { Mean of optical } \\
\text { density }\end{array}$ & *S/P ratio & $\begin{array}{c}\text { No. positive/no. } \\
\text { examined }\end{array}$ & Interpretation \\
\hline \hline 21 & 0.049 & 0.002 & $5 / 5$ & Negative \\
22 & 0.635 & 1.27 & $0 / 5$ & positive \\
23 & 0.047 & -0.002 & $0 / 5$ & Negative \\
24 & 0.047 & -0.001 & $0 / 5$ & Negative \\
25 & 0.048 & 0.0 & $0 / 5$ & Negative \\
26 & 0.07 & 0.047 & $0 / 5$ & Negative \\
27 & 0.05 & 0.004 & $0 / 5$ & Negative \\
28 & 0.047 & -0.002 & $0 / 5$ & Negative \\
29 & 0.05 & 0.004 & $0 / 5$ & Negative \\
30 & 0.048 & 0.001 & $0 / 5$ & Negative \\
uninoculated chicks & 0.046 & -0.005 & $0 / 5$ & Negative \\
\hline
\end{tabular}

- Negative control mean $(\mathrm{NCM})=0.048$

- Corrected positive control $(\mathrm{CPC})=0.46$
- Positive control mean $(\mathrm{PCM})=0.51$

* S/P ratio more than 0.5 was considered positive for REV antibodies

Table (3): Results of ELISA for detection of antibodies in serum samples from SPF chickens inoculated with pox vaccine sample No. 22.

\begin{tabular}{|c|c|c|c|c|c|c|c|c|c|}
\hline \multirow[b]{2}{*}{$\begin{array}{c}\text { Inoculated } \\
\text { chicks }\end{array}$} & \multicolumn{3}{|c|}{$15^{\text {th }}$ day post inoculation } & \multicolumn{3}{|c|}{$30^{\text {th }}$ day post post inoculation } & \multicolumn{3}{|c|}{$45^{\text {th }}$ day post post inoculation } \\
\hline & $\begin{array}{c}\text { Mean of } \\
\text { absorbance }\end{array}$ & *S/P ratio & $\begin{array}{l}\text { Interpre- } \\
\text { tation }\end{array}$ & $\begin{array}{c}\text { Mean of } \\
\text { absorbance }\end{array}$ & * S/P ratio & $\begin{array}{l}\text { Interpre- } \\
\text { tation }\end{array}$ & $\begin{array}{c}\text { Mean of } \\
\text { absorbance }\end{array}$ & $\begin{array}{l}* \mathrm{~S} / \mathrm{P} \\
\text { ratio }\end{array}$ & $\begin{array}{c}\text { Interpre- } \\
\text { tation }\end{array}$ \\
\hline & 0.22 & 0.53 & Positive & 0.64 & 1.28 & Positive & 0.81 & 1.46 & positive \\
\hline & 0.26 & 0.66 & Positive & 0.55 & 1.1 & Positive & 0.82 & 1.47 & Positive \\
\hline & 0.23 & 0.57 & Positive & 0.49 & 0.97 & Positive & 0.77 & 1.38 & Positive \\
\hline & 0.25 & 0.62 & Positive & 0.60 & 1.18 & Positive & 0.97 & 1.7 & Positive \\
\hline & 0.31 & 0.83 & Positive & 0.63 & 1.26 & Positive & 0.88 & 1.6 & Positive \\
\hline & 0.28 & 0.71 & Positive & 0.70 & 1.42 & Positive & 0.73 & 1.3 & Positive \\
\hline & 0.23 & 0.56 & Positive & 0.74 & 1.5 & Positive & 0.80 & $1 . .44$ & Positive \\
\hline & 0.24 & 0.61 & Positive & 0.63 & 1.27 & Positive & 0.86 & 1.5 & Positive \\
\hline & 0.24 & 0.60 & Positive & 0.54 & 1.06 & Positive & $0 . .70$ & 1.26 & Positive \\
\hline & 0.27 & 0.71 & Positive & 0.57 & 1.13 & Positive & 0.84 & 1.5 & Positive \\
\hline $\begin{array}{c}\text { Overall } \\
\text { mean }\end{array}$ & 0.25 & 0.64 & & $0 . .61$ & 1.2 & & 0.82 & 1.45 & \\
\hline $\begin{array}{l}\text { Uninoculated } \\
\text { chicks(control) }\end{array}$ & 0.043 & 0.02 & Negative & 0.057 & 0.002 & Negative & 0.06 & 0.005 & Negative \\
\hline
\end{tabular}

- Control data is overall mean of 5 uninoculated chicks.

* S/P ratio more than 0.5 was considered positive for REV antibodies.

- Over all mean of the S/P ratio of the sample 15 th days post inoculation $=0.64$

- Over all mean of the $\mathrm{S} / \mathrm{P}$ ratio of the sample 30 th days $\mathrm{PI}=1.2$

-Over all mean of the $\mathrm{S} / \mathrm{P}$ ratio of the sample 45 th days $\mathrm{PI}=1.45$

At 15th day post inoculation:

- Negative control mean $(\mathrm{NCM})=0.05$

- Positive control mean $(\mathrm{PCM})=0.37$

- Corrected positive control $(\mathrm{CPC})=0.32$

At 30th day nostinoculation:

$\overline{\text { Kafrelsheikh Vet. Med. J. Vol. } 6 \text { No. } 2 \text { (2008) }}$ 
- Negative control mean $(\mathrm{NCM})=0.056$

- Positive control mean $(\mathrm{PCM})=0.51$

- Corrected positive control $(\mathrm{CPC})=0.45$

At 45th day post inoculation:

- Negative control mean $(\mathrm{NCM})=0.063$

- Positive control mean $(\mathrm{PCM})=0.58 \quad$ - Corrected positive control $(\mathrm{CPC})=0.52$.

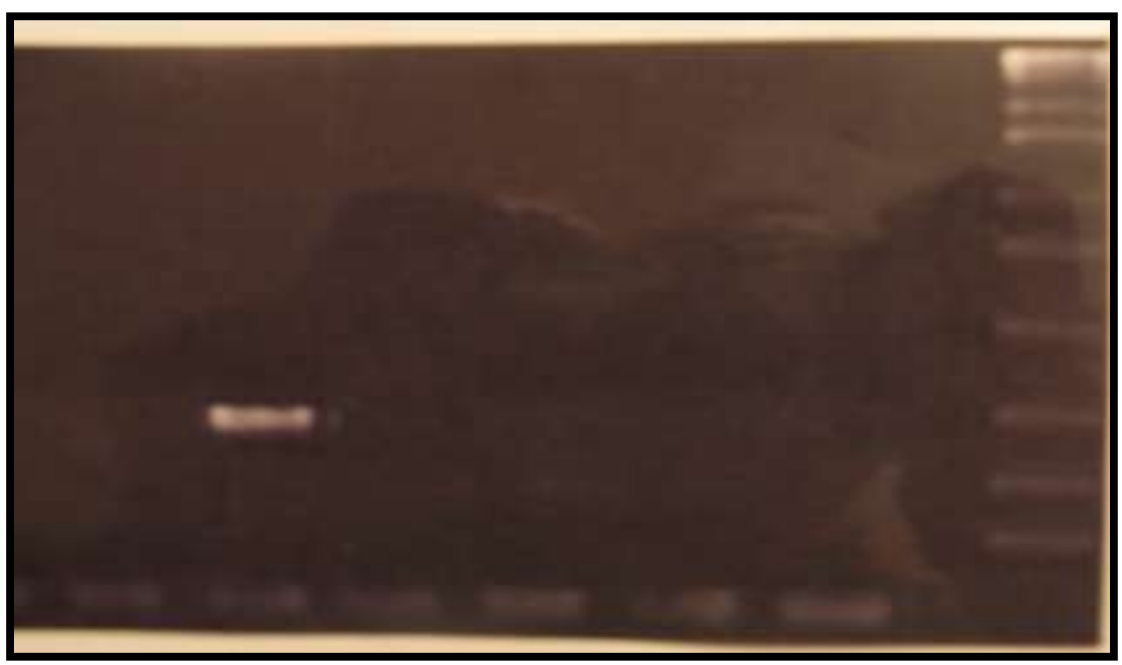

Fig. (1): Detection of REV proviral sequences in DNA of different fowl pox vaccine samples. A fragment of $291 \mathrm{bp}$ was detected in lane (3) (Lane 1: Negative control cell, Lane 2: Sample No. (21), Lane 3: Sample No. (22), Lane 4: Sample No. (23), Lane 5: Sample No. (24), Lane 6: Sample No. (25), Lane 7: Sample No. (26), Lane 8: Molecular size marker).

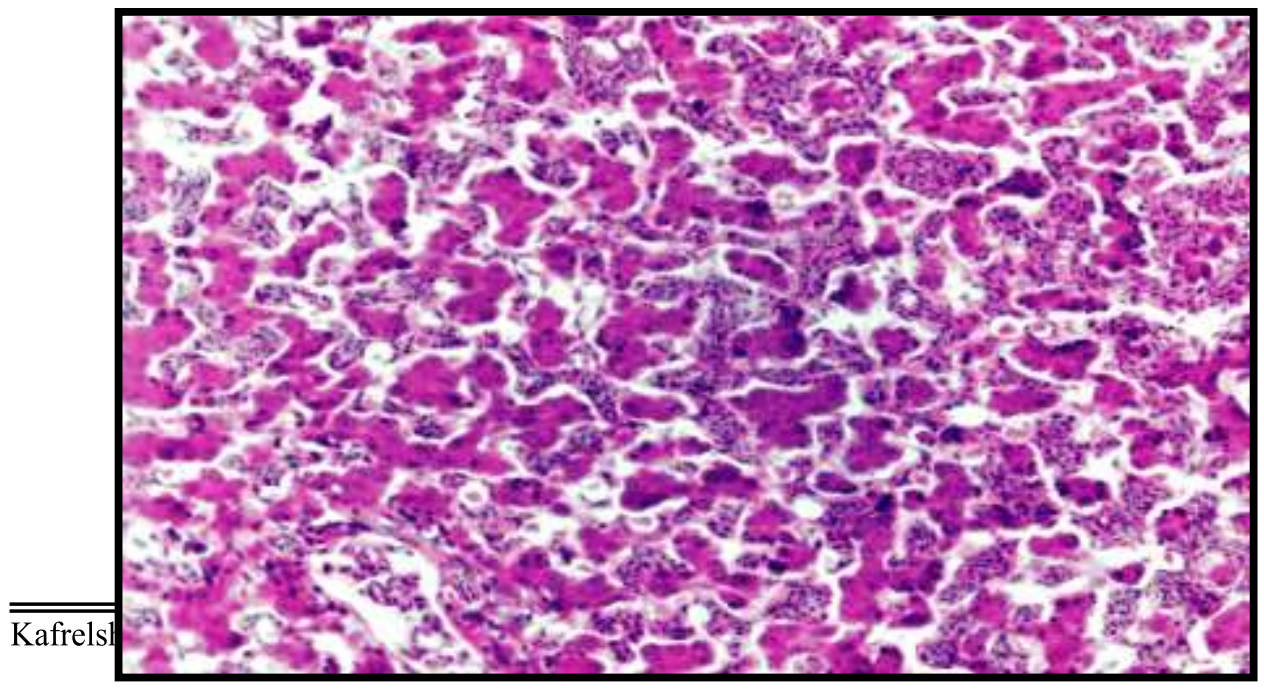


Fig. (2): Liver, 8 weeks PI showing marked atrophy of hepatic acinai as well as pronounced congestion of hepatic sinusoids (H \& E x 200)

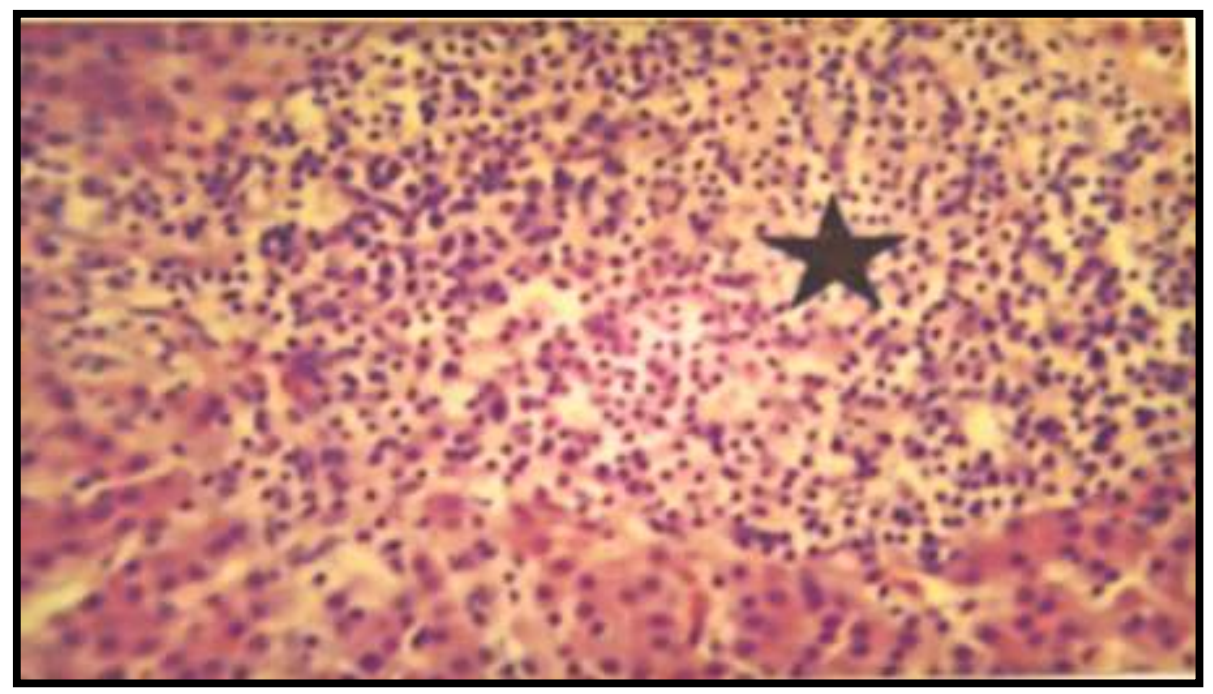

Fig. (3): Liver, 12 weeks PI showing focal area of infiltrations and aggregations of mononuclear histiocytic elements (reticuloendothelial elements) (asterisk)in between the severely degenerated and necrotic hepatocytic cells ( $\mathrm{H} \& \mathrm{E}$ x 400)

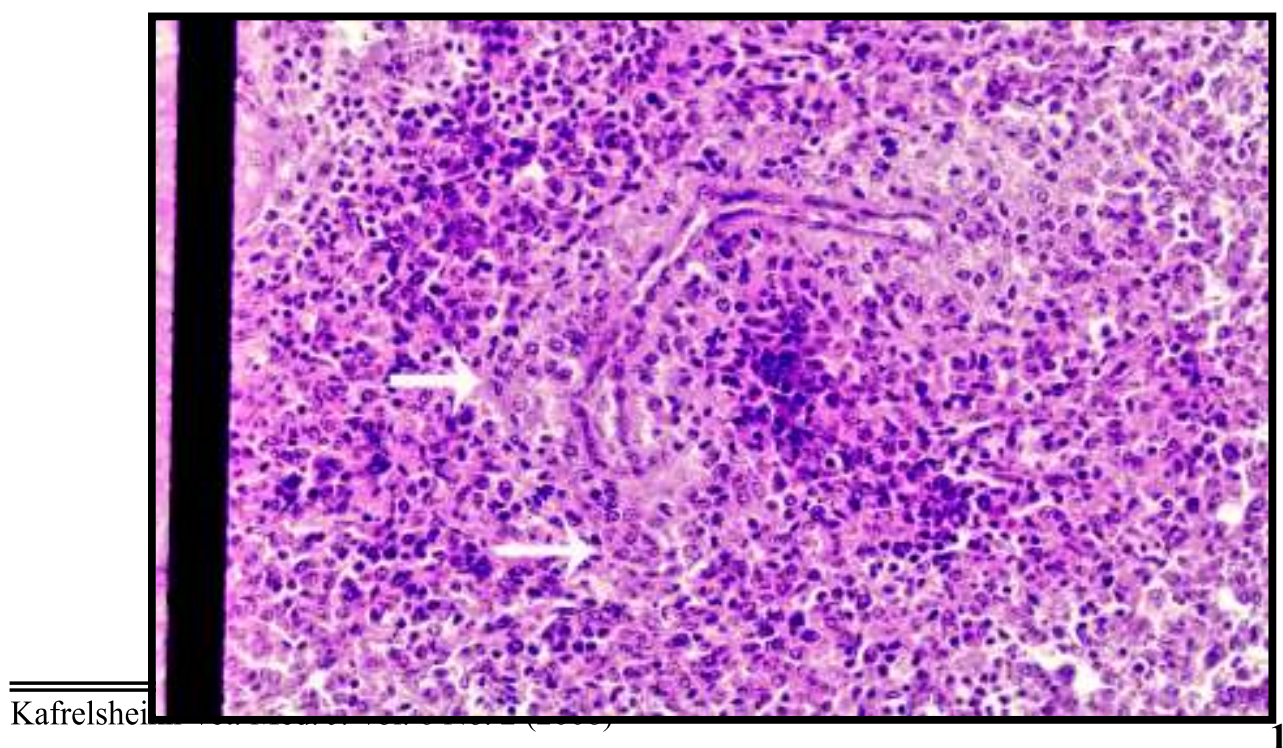


Fig. (4): Spleen, 8 weeks post infection showing excess of the proliferated mononuclear cells of the reticuloendothelial elements around arterioles ( $\mathrm{H} \& \mathrm{E}$ x400).

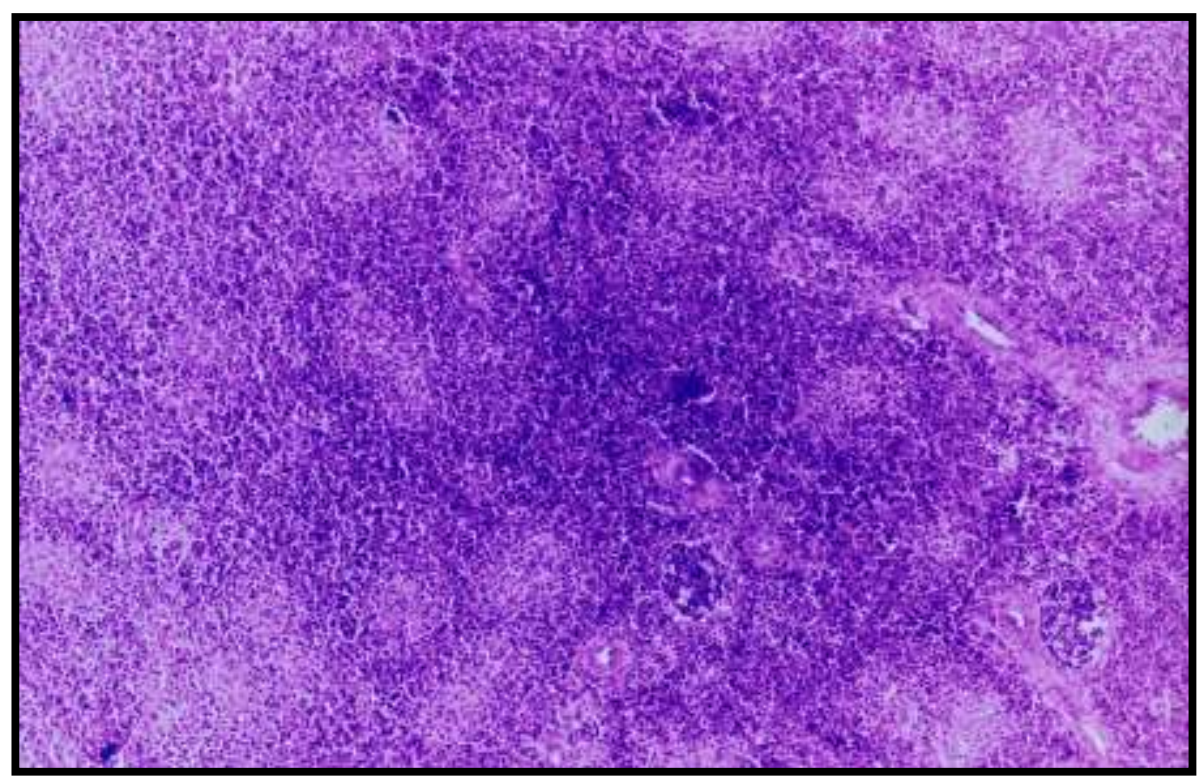

Fig. (5): Spleen, 12 weeks PI showing diffuse focal proliferation of mononuclear cells of the reticuloendothelial elements ( $\mathrm{H} \& \mathrm{E} \times 50)$

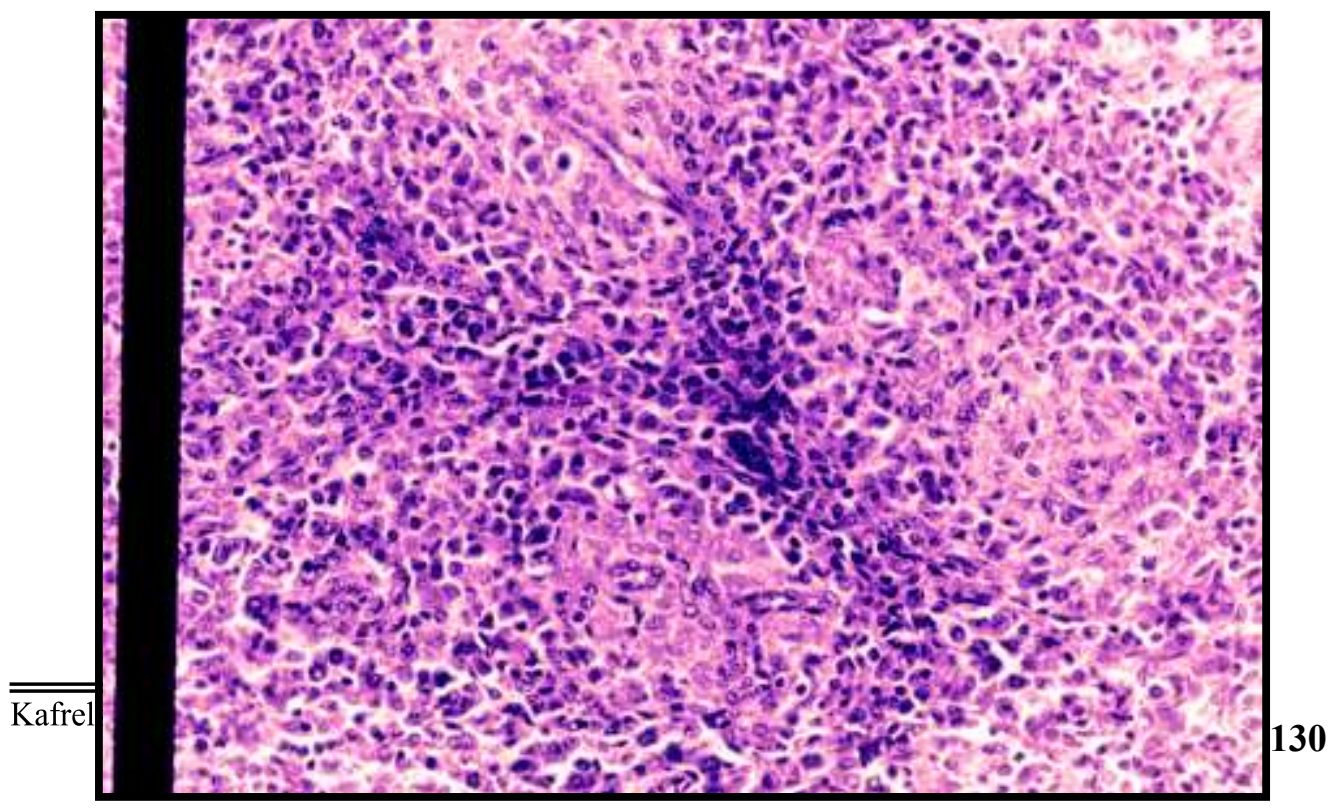


Fig. (6): Spleen, 12 weeks PI showing moderate magnification of Fig. (5), notice vesicular nucleus and margination of chromatin (H \& E x200)

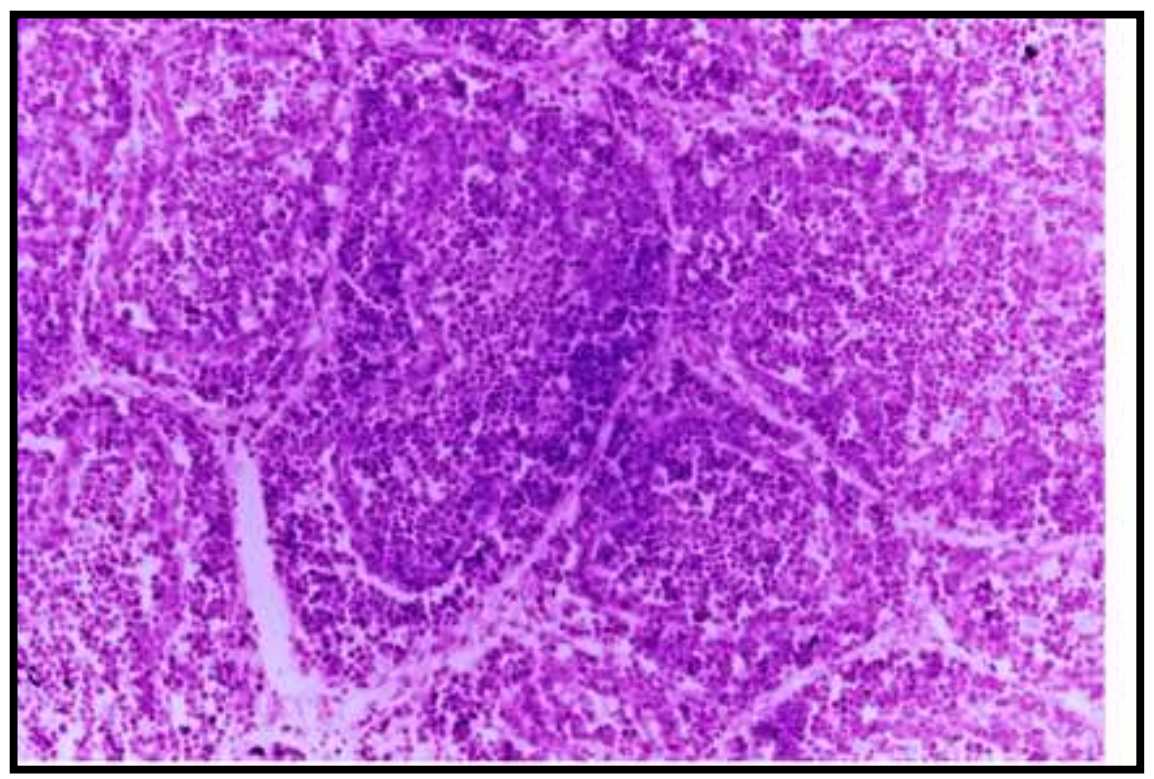

Fig. (7): Bursa of Fabricius, 8 weeks post infection showing diffuse mononuclear cells of the reticuloendothelial elements infiltration in most of the lymphoid follicles ( $\mathrm{H} \& \mathrm{E}$ x200)

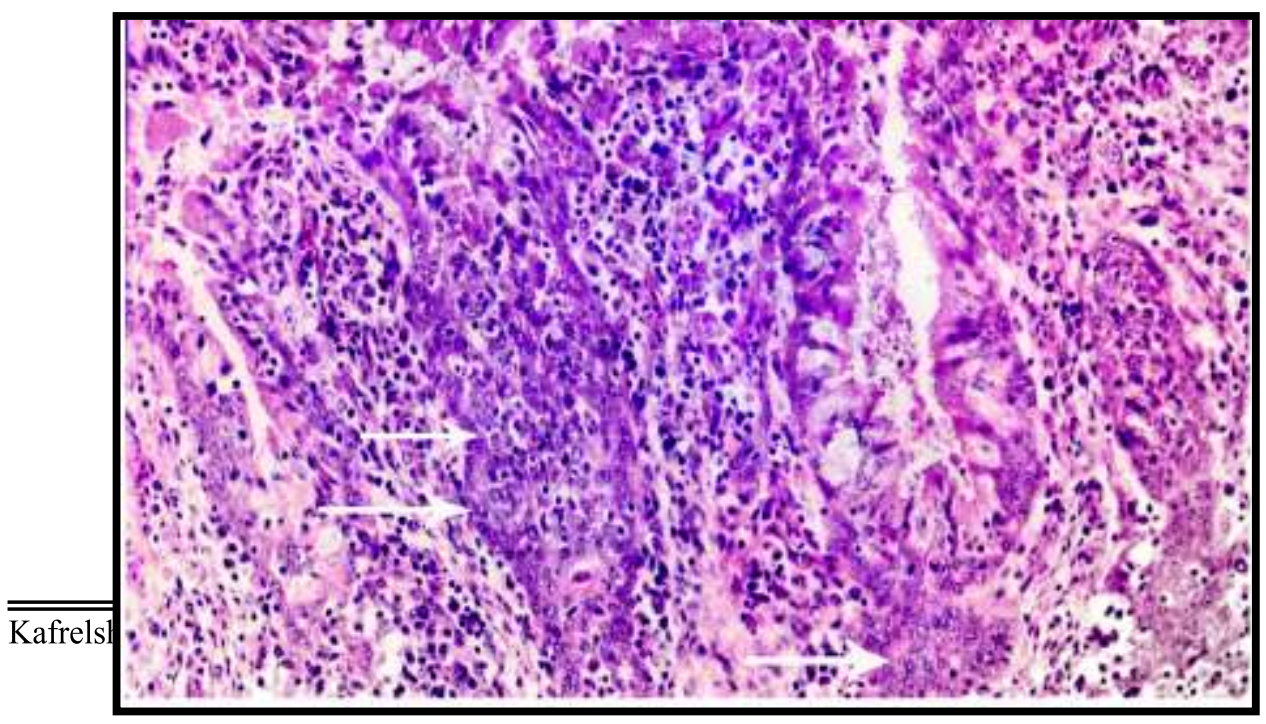


Fig. (8): Bursa of Fabricius, 12 weeks PI showing inter \& intra follicular aggregations of mononuclear cells of the reticuloendothelial elements (arrows) (notice atrophy of the follicles) (H \& E x200)

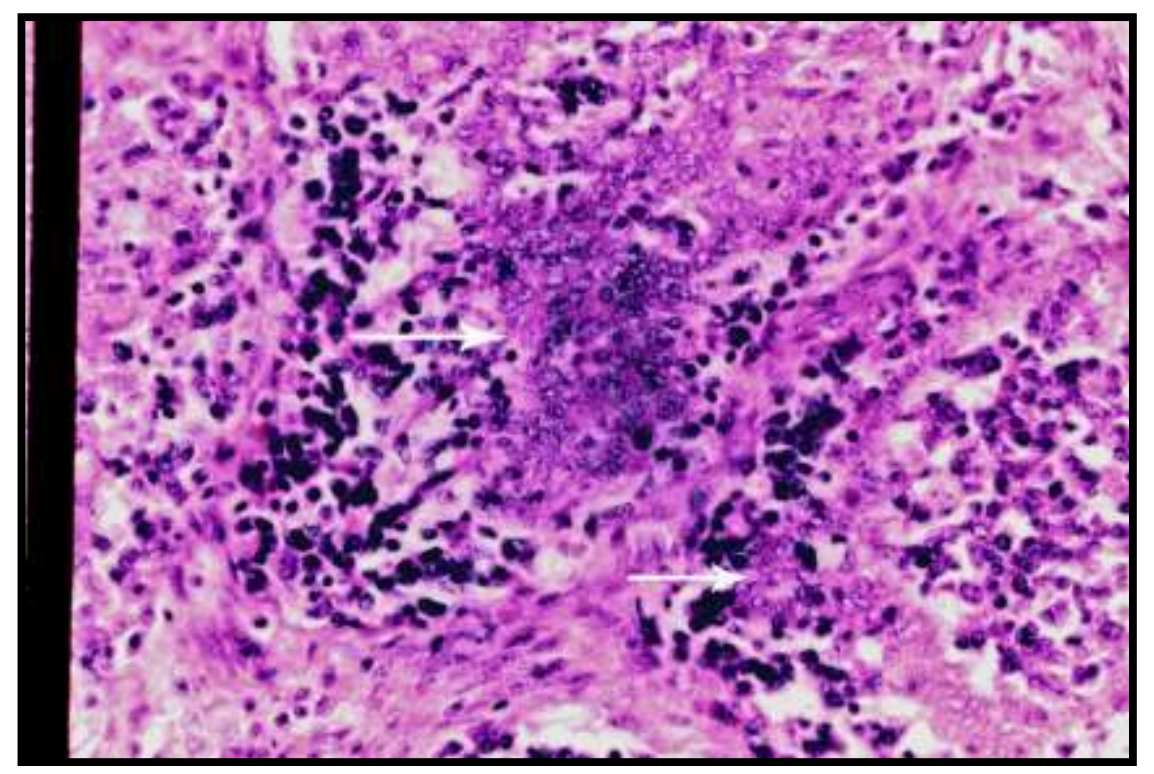

Fig. (9): Bursa of Fabricius, 12 weeks PI showing infiltration of mononuclear cells of the reticuloendothelial elements inter \& intra follicular with pronounced follicular atrophy(H \& E x400)

\section{DISCUSSION}

In the present study, thirty batches of fowl pox virus vaccines collected from different sources (locally and imported vaccines) were screened for the detection of REV as contaminant. Vaccines were tested by two assays, the in vitro assay using CEF cultures then PCR for detection of REV equence using the 5 LTR primers, and the in vivo assay by inoculation of fowl pox vaccines in five days old SPF chicks, 
detection of REV antibodies by ELISA test and histopathological examination of the internal organs.

Results of the in vitro assay revealed that one batch of FPV vaccines out of thirty $(3.33 \%)$ was positive in PCR test. A product of 291 bp were obtained, as reported by Witter and Fadly (2003), who detected the proviral DNA by PCR assays that amplify the $291 \mathrm{bp}$ product of REV LTR has been shown to be a sensitive and specific method for detection of various strains of REV in CEF cultures as well as in blood and tumors of infected chickens. The percentage of positive vaccines $(3.33 \%)$ is relatively low when compared to that obtained by Garcia et al.( 2003) who examined field isolates and vaccines of fowl pox virus for detection of REV by PCR using two types of primers: the 5 LTR primer and env. sequence primer. They found that all field isolates gave positive results with both primers while $50 \%$ of the examined vaccine strains were amplified only with REV 5 LTR primer but not with the env. Sequence primer. These results were also related to the obtained results by Diallo et al.( 1998) and Kim and Tripathy (2001) when they found that none of the examined vaccinal strains contain env. sequence while 12 of 17 tested vaccines were positive for REV when they used the 5 LTR primer. The difference in percentage of positive vaccines in these reports and our study may be due to that the tested FPV vaccines were produced by different manufactures and imported from many countries and it may not exactly contain the same strain in each time. Also, may be due to that we used one primer (5 LTR) while other studies used two primers (the 5 LTR and env. sequence primer). However, Hertig et al. (1997) reported that PCR amplification was obtained for one of the four vaccine strains with REV env. sequence. The results of in vivo assay are correlated with that of in vitro assay. 
Antibodies against REV were detected in one group of chickens (the group which inoculated by pox vaccine sample No. (22) ) and gave positive result by PCR. REV antibodies were firstly detected at 15 th day post inoculation using ELISAtest and this result agreed with that reported by Motha, (1984) who detected REV antibodies in inoculated chickens as early as 16 days post inoculation. However, Aly et al. (1993) detected REV antibodies at 3 weeks post inoculation and not before. On the other hand, Fadly and Witter, (1997) failed to detect REV antibodies in SPF chickens inoculated at 5 days old with REV contaminated fowl pox vaccine neither at 3 nor 4 weeks post inoculation using the immunofluorescence (IF) assay. This discrepancy in results of Fadly and Witter, (1997) and that obtained by other workers may arise from that Fadly and Witter, (1997) used a contaminated fowl pox vaccine as inoculum while Motha, (1984) and Aly et al. (1993) used a pure REV preparations. These results suggesting that the dose of RE virus in the inoculum may play role in the response of chickens and also the presence of other agents (fowl pox virus in our study) may interfere with the response of inoculated chickens to produce antibodies against REV. Another factor could attributed to that the detection of REV antibodies in the present study was carried out using ELISA test while other researchers used the IF assay. These results indicated that, the ELISA test has shown to be most sensitive and specific method for detection of REV antibodies which supported by Smith and Witter (1983).

In this study a specific REV neoplastic lesions in liver, spleen and bursa were observed at $8^{\text {th }}$ and $12^{\text {th }}$ week post inoculation, and this agrees with results obtained by (Bohls et al., 2006) who detect neoplasia at $8^{\text {th }}$ week post inoculation of prairie chickens with REV. 
Finally, we can conclude that contamination of vaccine, partial or complete insertion of REV genome in other viruses and developing new control method represent important challenge that must be addressed in order to develop effective strategies for control of REV infection in poultry and for obtaining maximum vaccination results.

\section{REFERENCES}

- Abdel Hamid, A.A. (1997): A study on some viral contaminants in live poultry vaccines. M.D.V. Thesis.

- Aly, M.A.; Smith, E.J. and Fadly, A.M. (1993): Detection of reticuloendotheliosis virus infection using the polymerase chain reaction. Avian Pathol., 22: 543-554.

- Bagust, T.J. (1993): Reticuloendotheliosis virus. In J.B. Mcferran and M.S.Mcnulty (eds.) virus infections of vertebrates, 4- virus infections of birds. Elsevier science publishers B.V.: Amsterdam, 437-454.

- Bagust, T.J. and Dennett, D.P. (1977): Reticuloendotheliosis virus: Experimental infection of poultry and immunofluorescent identification of Australian isolates. Aust. Vet. J., 53:506-508.

- Bancroft, J.D., and Stevens, A. (1996): Theory and practice of Histological techniques. Fourth Edition.

- Bohls, R.L.; Collisson, E.W.; Gross, S.L.; Silvy, N.J. and Phalen, D.N. (2006): Experimental infection of Attwater's/greater Prairie chicken hybrids with the reticulloendotheliosis virus. Avian Dis., 50: 613-619.

- Diallo, I.S.; Mackenzie, M.A.; Spradbrow, P.B. and Robinson, W.F. (1998): Field isolates of fowl pox virus contaminated with reticuloen- 
dotheliosis virus. Avian Pathol., 27: 60-66.

- Dren, C.N.; Nemeth, I.; Sari ,I.; Ratz, F.; Glavits, R. and Somogyi, $\boldsymbol{P}$. (1988): Isolation of reticuloendotheliosis like virus from naturally occurring lymphoreticular tumors of domestic goose. Avian Pathol., 17: 259-277.

- Fadly, A.M. and Garcia, M.C. (2006): Detection of reticuloendotheliosis virus in live virus vaccine of poultry. Dev. Biol. (Basel)., 126: 301-327.

- Fadly, A.M. and Witter, R.L. (1997): Comparative evaluation of in vitro and in vivo assays for the detection of reticuloendotheliosis virus as a contaminant in a live virus vaccine of poultry. Avian Dis., 41: 695-701.

- Fadly, A.M.; Witter, R.L.; Smith, E.J.; Silva, R.F.; Reed, W.M.; Hoerr, F.J.and Putnam, M.R. (1996): An outbreak of lymphomas in commercial broiler breeder chickens vaccinated with a fowl pox vaccine contaminated with reticulo-endotheliosis virus. Avian Pathol., 25: 35-47.

- Garcia, M.; Narang, N.; Reed, W.M. and Fadly, A.M. (2003): Molecular characterization of reticuloendotheliosis virus insertions in the genome of field and vaccine strains of fowl pox virus. Avian Dis., 47: $343-354$.

- Hertig,C.; Coupar, B.E.; Gould, A.R. and Boyle, D.B. (1997): Field and vaccine strains of fowl pox virus carry integrated sequences from the avian retrovirus, reticuloendotheliosis virus. Virology, 235 (2): 
367-376.

- Jackson,C.A.W.;Dunn,S.E.;Smith,D.L.; Gilchrist and MacQueen, P.A (1977): Proventriculitis, "Nnkanuke" and reticuloendotheliosis in chickens following vaccination with herpes virus of turkeys (HVT). Aust.. Vet. J., 53: 457-458.

- Kim, T.J. and Tripathy, D.N. (2001): Reticuloendotheliosis virus integration in the fowl pox virus genome: not a recent event. Avian Dis., 45: 663-669.

- Meroz, M. (1992): Reticuloendtheliosis and pullet disease in Israel. The Veterinary Record, 130: 107-108.

- Motha, M.X.J. (1984): Distribution of virus and tumor formation in ducks experimentally infected with reticuloendotheliosis virus. Avian Pathol., 13: 303-320.

- Nicholas, R.A.J. and Thornton, D.H. (1983): Relative efficiency of techniques for detecting avian reticuloendo-theliosis virus as a vaccine contaminant. Research in Veterinary Science, 34: 377-379.

- Okoye, J.O.A.; Ezema, W. and Agoha, J.N. (1993): Naturally occurring clinical reticuloendotheliosis in turkeys and chicken. Avian Pathol., 22: 237-244.

- Paul, I.; Cotofan, O. and Boisteanu, M. (1986): The incidence of Marek's disease in anti-MD vaccinated hens. IASI Lucr Stiint Ser Zooteh Med. Vet., 30: 95-96.

- Singh, P.; Kin, T.J. and Tripathy, D.N. (2003): Identification and 
characterization of fowl pox virus strains using monoclonal antibodies. J. Vet. Diagn. Investig., 15: 50-54.

- Singh,P.;Schnitzlein, W.M. and Tripathy, D.N.(2005): Construction and characterization of fowl pox virus field isolate whose genome lacks reticuloendotheliosis provirus nucleotide sequences. Avian Dis., 49: 401-408.

- Smith, E.J. and Witter, R.L. (1983): Detection of antibodies against reticuloendotheliosis virus by enzyme-linked immunosrbant assay. Avian Dis., 27:225-234.

- Tadese, T., Fitzerald, S. and Reed, W.N. (2008): Detection and differentiation of re-emerging fowl pox virus(FPV) strains carrying integrated reticuloendotheliosis virus (FPV-REV) by real time PCR. Vet. Microbiol., 127 :39-49.

- Witter, R.L. (1991): Reticuloendotheliosis. Diseases of Poultry. 9th ed. Iowa state Univ. Press., Ames, Iowa, PP 439 - 456.

- Witter, R.L and Fadly, A.M. (2003): Reticuloendotheliosis virus. In Disease of Poultry 2003,11th Edition, edit, Saif, Y..M; Barnes, H.J; Glisson, J.R.; Fadly A.M; McDougald, L.R. and Swayne, D..E.: $517-536$.

- Yuasa, N., Yoshida, I. and Taniguchi, T. (1976): Isolation of a reticuloendotheliosis virus from chickens inoculated with Marek's disease vaccine. National Institute of Animal Health Quarterly 16: 141 - 151. 